\title{
TRIANON ÉS A BRIT FÖLDRAJZ I.
}

\author{
GYŐRI RÓBERT - CHARLES W. J. WITHERS
}

\author{
BRITISH GEOGRAPHY AND THE TRIANON PEACE TREATY (PART 1)
}

\begin{abstract}
The 'dismemberment' of Hungary as a result of the Treaty of Trianon (1920) was a momentous event. This paper examines the reaction of British geographers to Hungary's dramatic and extensive loss of territory and much-reduced national sovereignty. It considers two works by British geographers, Marion Newbigin (in 1920) and Alan Ogilvie (in 1922), who attempted to explain Hungary's situation following the Treaty. To Hungary's geographers, Trianon ruptured historical associations between nature and nation. Boundaries previously formed upon the Carpathians' natural geography and the hydrography of the Great Hungarian Plain were now replaced by ethnic considerations, even although these proved difficult to effect in practice as the basis of the new boundaries. The paper explores maps produced by Hungarian geographers, and most notably Pál Teleki's 'Ethnographical Map of Hungary' (1919) - the so-called 'Carte Rouge'-which attempted to reveal Hungary's ethnic identity and territorial integrity. The paper then examines Marion Newbigin's 'Aftermath: A geographical study of the peace terms' (1920) and Ogilvie's 'Some aspects of boundary settlement at the peace conference' (1922) as Britain's geographers tried to explain and justify Trianon in terms of post-war geopolitics, ethnic diversity, and linguistic difference. For Newbigin, Hungary's ethnic delimitation post-Trianon was largely dictated by the Western powers (principally by the American delegation to the 1919 Paris peace conference). In his work Ogilvie (a member of the British geographical delegation in Paris) shows that the principles on which Trianon was determined were often compromised in practice. The paper shows how the new geography of Europe and Hungary dictated by Trianon elicited different responses from different geographical communities.
\end{abstract}

Keywords: Hungary; Treaty of Trianon; World War I; British geography

\section{Bevezetés}

„Egyetlen békeszerzódés határozatai sem voltak drasztikusabbak a trianoni szerzódésnél. Ez nemcsak megcsonkította, hanem fel is darabolta Magyarországot." (MACARTNEY, C. 1937, p. 1.)

Amikor 1918 őszén a nagy háború frontjain elcsendesedtek a harcok, a győztes szövetségesek és az összeomlott központi hatalmak egyaránt a békekötésre készültek. A békekötés előkészületei a geográfusokat újra csatasorba állították: a határváltozások tudományos alátámasztása, az államterület integritásának védelme vagy az új (esetleg megnagyobbodott) nemzetállami tér tudományos megindoklása földrajzos szaktudást igényelt. Az addig fóként akadémiai munkának élô földrajzosok állami szolgálatba léptek: a békedelegációk munkájában - elsősorban a határmegvonások szakértőiként - geográfusok is szerepet kaptak. Míg az amerikai, európai és brit geográfusok II. világháborús részvételével több elemzés (ACKERMAN, E. 1945; BALCHIN, W. 1987; MADDRELL, A: 2008; Clayton,D.-BARNeS, T. 2015) is foglalkozott, addig alig született olyan tanulmány, amely a brit földrajzosok szerepét kutatta volna az I. világháborút lezáró békekötéseknél. Ezért is fontos MicHAEL HEFFERNAN (1996) elemzése, ami rámutatott arra, hogy a Brit Királyi Földrajzi Társaság (Royal Geographical Society - RGS) már 1914 elôtt bekapcsolódott brit katonai térképezésért felelős hivatal (Ordnance Survey - OS) és a brit vezérkar földrajzi csoportjának (Geographical Section of the General Staff - GSGS) munkájába. Az RGS földrajzi ada- 
tokat és feldolgozásokat szolgáltatott a katonai stratégiaalkotáshoz, a birodalom határvidékeinek térképezéséhez és az 1891-ben ALBRECHT PENCK német geomorfológus által kezdeményezett 1:1 milliós világtérkép munkálataihoz. 1914 derekára az RGS már „a hadügymisztérium térképészeti és technikai részlegévé" vált (HEFFERNAN, M. 1996, p. 509). Ezekbe a munkákba bekapcsolódott a birodalom térképezési feladataiban hírnevet szerzett Sir Thomas Holdich ezredes, Sir Walter CoOte Hedley ezredes, a GSGS vezetője, és ARTHUR HINKS csillagász, aki 1915-tól egyszerre volt az RGS titkára és a társaság folyóiratának a Geographical Journalnek a szerkesztője. 1914-től ők és az általuk vezetett intézmények elsősorban a Közel-Kelet és Észak-Afrika 1:1 milliós térképének elkészítésével foglalkoztak, 1916-tól kezdve azonban az európai nyugati front térképezésére és katonai stratégiai kérdéseire koncentráltak. A párizsi béketárgyalásokon a brit földrajzosok a GSGS keretében vették részt. A kis létszámú földrajzos szakértői csoportot HEDLEY vezette, és „tagja volt O. E. Wynne örnagy és Alan G. Ogilvie kapitány, aki a brit delegáció térképészeti tanácsadója volt" (HeFFERnAN, M. 1996, p. 520). A brit geográfus szakértői csoport méretében és befolyásában is alulmaradt más országok földrajzos delegációja mellett, ahogy HeFFERnAN, M. (1996) fogalmaz: „Az a kudarc, hogy a brit geográfusok nem játszottak fontos szerepet a béketárgyaláson, valószínúleg visszavezethető a tudományterület Nagy-Britanniában ez idő tájt döntốn amatôr jellegére" (p. 521).

Kétrészes tanulmányunk HEFFERNAN idézett elemzéséhez hasonlóan egy olyan kísérlet, ami „a földrajz és a háború összetett kapcsolatát vizsgálja 1914 és 1919 között” (HEFFERnAN, M. 1996, p. 505). Fontos különbség a két vállalkozás között, hogy míg HEFFERNAN tanulmánya a brit földrajz és a brit földrajzosok első világháborús tevékenységét kutatta, addig a mi munkánk fókuszában egyrészt a brit geográfusoknak a háborút lezáró béketárgyalásokban játszott szerepe, másrészt a trianoni békeszerződéssel kapcsolatos véleménye, reakciója áll.

Trianon tényei jól ismertek. A 14 részből és 362 cikkelyből álló dokumentum rendelkezései elcsatolták Magyarország területének kétharmadát, lakosságának 60\%-át. Az ország területéből hat állam (Ausztria, Csehszlovákia, Lengyelország, Románia, a Szerb-HorvátSzlovén Királyság és Olaszország) részesedett. Magyarország területi veszteségei messze meghaladták Németországét, amelyet a győztes hatalmak a háború legfontosabb felelősének tartottak. Az ország feldaraboldásának traumája a magyar társadalom máig élő tehertétele. Trianon tényei tehát ismertek, a brit földrajznak a békeszerződés előkészítésében játszott szerepe, és annak következményeirôl alkotott véleménye azonban sokkal kevésbé.

Dolgozatunknak ezért az a fó célja, hogy párizsi brit szerepvállalást vizsgálja, és a brit földrajzosoknak Trianon hatásaival, Magyarország feldarabolásával kapcsolatos szakmai álláspontját tisztázza. Kutatásunk során egyrészt levéltári forrásokat (elősorban levelezéseket, naplókat) tártunk fel, másrészt nyomtatásban megjelent tanulmányokat, köteteket dolgoztunk fel, hogy az egyes geográfusok és a fontos intézmények (mindenekelőtt az RGS és a British Association for the Advancement of Science - BAAS) szerepét felderítsük. Az érintett földrajzosok közül kiemelkedik ALAN OGILVIE, aki a párizsi brit delegáció egyik geográfusa volt, 1923 után pedig az Edinburgh-i Egyetem adjunktusa, docense, majd 1931-től tanszékvezető professzora lett. Ugyanígy fontosnak bizonyult MARION NEWBIGIN (a Scottish Geographical Magazine szerkesztője) és a gazdaságföldrajzos JoHn MCFARLANE munkásságának elemzése. A történész képzettségú McFARLANE 1903-tól a Manchesteri Egyetem földrajzos adjunktusa volt, majd 1919-ben az Aberdeeni Egyetem első geográfus egyetemi oktatója lett. Az I. világháború alatt az említett ARTHUR HiNKSszel és más földrajzosokkal (mint pl. HeNRY N. Dickson és R. N. RuDMOSE BROwN) együtt részt vett haditengerészeti és katonai földrajzi kézikönyvek elkészítésében (Naval Intelligence Department 1919). OGILVIE töltötte be McFARLANE megüresedett pozícióját a Manchesteri 
Egyetemen 1919 augusztusa és 1920 májusa között, majd 1920 júniusában New Yorkba költözött, hogy az Amerikai Földrajzi Társaság (American Geographical Society - AGS) munkatársaként az 1:1 milliós térkép elkészítésében vegyen részt. Itt IsAIAH BowMANnel dolgozott együtt, aki Párizsban az amerikai delegáció földrajzos csoportját vezette.

Tanulmányunk első részében felvázoljuk a későbbi részletes elemzés hátterét. Bemutatjuk a földrajzos delegációk munkáját Párizsban, a magyar geográfusok érvrendszerét, továbbá magyaroknak a külföldi kollégák, illetve a külföldi közvélemény meggyőzése érdekében tett erőfeszítéseit. Ezt követően a brit földrajzosoknak Magyarország kérdéséról és az új magyar határokról alkotott véleményét két fontos kötet elemzésével tárjuk föl. Az egyik MARION NewBIGIN 1920-ban megjelent Aftermath: A geographical study of the peace terms címú könyve, a másik ALAN OGILVIE 1922-es Some aspects of boundary settlement at the peace conference címú kötete. NEWBigin 128 oldalas munkája a legrészletesebb kortárs brit földrajzi értekezés Európa határainak az I. világháborút követő átrendezéséről, ennek ellenére a mai kutatók elemzéseiből - pl. DHAND, O. (2018), SMiTh, N. (2003) vagy SEEGEL, S (2018) munkájának irodalomjegyzékéből is - hiányzik. OGILVIE 1922-es rövidebb kötete szintén egy elfeledett munka, pedig szerzője azok közé a brit geográfusok közé tartozott, akik Párizsban ténylegesen részt vettek a határok kialakításában.

Az 1919. január 1-jén kezdődő párizsi békekonferencia rendelkezéseinek bonyolult hatását sokan elemezték, az első részletes angol nyelvű összefoglaló munka a kortárs TEMPERLEy, H. tollából már 1920-ban megjelent. Többen foglalkoztak a szakértôként dolgozó geográfusok szerepével, különösen IsAIAH BOWMAN és amerikai kollégáinak a tevékenységével (SMith, N. 2003; Reisser, W. 2012; MARTin, G. 2015) vagy EugENiUSZ Romer és Jovan Cvijić múködésével (SEegel, S. 2018; KonOPSKA, B. 2016; LabBé, M. 2018; GinsBurger, N. 2016). A téma kiemelt magyarországi fontossága miatt a magyar földrajzosok erófeszítéseit is több munka tárgyalta (HAJDÚ Z. 2000; KRASZNAi Z. 2012; SEgYeVy D, 2016), különösen jól feltárt TELEKI PÁL pályája, életútját monografikusan is feldolgozta ABLONCZY BALÁZS, akinek a legfrissebb, népszerúsítő összegzése a közelmúltban (2018) jelent meg. Trianonról több átfogó munka jelent meg magyarul. Ezek közül a legtöbbet olvasott kötet minden bizonnyal Romsics IGNÁc (2001) több kiadást megért, kiegyensúlyozott álláspontot elfoglaló könyve. A magyar békeküldöttség párizsi múködését is elég részletesen ismerjük a küldöttség naplójának friss kiadásából (ZEIDLER M. 2017a), valamint ZEIDLER MiKLós (2017b) alapos kísérőtanulmányából.

\section{A geográfusok béke-elókészítő munkája}

A békedelegációk tevékenységének részletes dokumentálása nem célja ennek a tanulmánynak, írásunkban ezért elsősorban a brit földrajzos szakértői csoport és OGILVIE munkájára fókuszálunk. Elengedhetetlen azonban, hogy röviden bemutassuk a geográfusok párizsi múködését. A győztes országok delegációinak tagjai voltak a földrajzos szakértők: nemcsak Nagy-Britannia, Franciaország és az Egyesült Államok küldöttségében dolgoztak földrajzosok, hanem az új, újjászülető vagy területükben jelentősen gyarapodó középeurópai államok is bevonták saját geográfus szakembereiket. A francia delegáció a francia külügyminisztérium földrajzi csoportjára támaszkodott, emellett a Service Géographique de l’Armée és a Párizsi Földrajzi Társaságból életre hívott Service Géographique Français is segítette munkáját. Ez azt is jelentette, hogy az ország leghíresebb geográfusai (többek között Emmanuel de Martonne, Emmanuel de Margerie, Albert Demangeon, LUCIEN GALLOIS és JEAN BRUNHES) „,erös befolyást tudtak gyakorolni a békekonferencián a francia álláspontra" (HEFFERNAN, M. 1996, p. 520; továbbá HEFFERNAN, M. 1995). 
Az amerikai békedelegáció igazán nagyszabású volt: összesen 1248 ember (köztük 150 tudós szakértő) kapcsolódott be a munkába (SMITH, N. 2003). Névlegesen a WoodROW WILSON elnök által kinevezett EDWARD MANDELL HouSE ezredes állt a bizottság élén, azonban az Amerikai Földrajzi Társaság (AGS) igazgatója, IsAIAH BowMAN szervezte munkát, és a „House Inquiry” az AGS New York-i irodáiba költözött be. BowmAN egyike volt az amerikaiak négy geográfus tanácsadójának, sőt ő lett ,az amerikai delegáció elsô számú szaktekintélye területi kérdésekben" (SMITH, N. 2003, p. 143). Mellette dolgozott még Douglas Johnson a Columbia Egyetemről, MARK JEFFERSOn a Michigan State Normal Schoolról, továbbá rövid ideig LAWRENCE MARTIN a Wisconsini Egyetemről. JEFFERSON vezette a „,öldrajz és térképezés” szekciót, JoHNSON pedig a határok topográfiájával foglalkozó szekciót. Jovan CVIJIĆnek, a Belgrádi Egyetem professzorának népességföldrajzi munkái és etnikai térképei a leendő Szerb-Horvát-Szlovén Királyság születését segítették elő (GINSBURGER, N. 2016). Hasonló szerepet töltött be a politikai földrajzos és kartográfus EuGENIUSZ ROMER a lengyel delegáció tanácsadójaként (KONOPSKA, B. 2016; LABBÉ, M. 2018; SEEGEL, S. 2018). A háromfős brit földrajzos szakértői csoport (HEDLEY, WYNNE, valamint 1919 júniusáig OGILVIE) „a brit delegációt és a békekongresszust nagy mennyiségü térképpel látta el. A munkához a nyomdatechnikát a Royal Engineers W. Stanford örnagy vezette térképészeti szekciója biztositotta" (n. n. 1920, p. 312 - a szerző valószínúleg HinKs, A. volt).

A párizsi béke-előkészítő munkába bekapcsolódó geográfusok jelentős része személyesen is ismerte egymást, mivel részt vettek a WILLIAM MORRIS DAVIS amerikai geomorfológus által szervezett 1912-es nyolchetes, $22500 \mathrm{~km}$-t felölelő amerikai transzkontinentális utazáson. A francia szakértők közül Demangeon, Gallois, DE MARTONnE és DE MARGERIE, a britek közül OGILVIE, az amerikaiak közül JOHNSON, JEFFERSON és BOWMAN nevét találjuk meg a résztvevők névsorában. A magyar béke-előkészítést irányító TELEKI PÁL és CHOLNOKY JENŐ szintén ott voltak az úton, sőt TELEKI halála után 1942-ben CHOLNOKY meg is jelentette visszaemlékezéseit az útról. A delegációkon belül zajló szakértői munka és delegációk közötti szakmai eszmecsere tehát meglévő kapcsolatrendszerre épült, aminek az alapját az amerikai terepmunka közös élményei adták (CLOUT, H. 2005; MACLEAN, K. 2011). Különösen OGILvIE és JoHNSON esetében igaz, hogy a párizsi tartózkodás tovább erősítette a kapcsolatokat. A brit delegáció az Hôtel Majesticba kvártélyozott be, az amerikai az Hôtel de Crillont foglalta le. OGILviE, JoHnson és a többiek együtt éltek társadalmi életet, a béke-előkészítés problémái gyakran a közös vacsorákon is előkerültek.

A geográfusok munkája egyaránt kiterjedt a térképek tervezésére és megrajzolására, illetve a határmegvonással és a lehetséges következményekkel kapcsolatos tanácsadásra. A térképezés a nemzetiségi szempontot követte (az anyanyelvi adatok feltüntetésével), a fiziográfiát vagy a természeti képződményeket követô határok elve háttérbe szorult. (A brit földrajzosok közül többen is furcsállották ezt a megközelítést.) Kontinentális léptékben ez az „etnikai kartográfia” (SMITH, N. 2003, p. 174) európai emberek tízmillióinak sorsát, identitását változtatta meg, és elvetette egy még nagyobb konfliktus magvait (SMITH, N. 2003: SEEGEL, S. 2018). Lokális léptékben, a békeszerződés helyszínén azonban a térképek episztemikus értékének az elismerése egyéni kapcsolatokra és információcserére épülő hálózatoknak a függ vénye volt. Ez többféle hálózatot jelentett: a különböző nemzeti küldöttségeknek tanácsot adó geográfusok összeköttetéseit, illetve egymás közötti kapcsolatait, továbbá a Párizsban múködő földrajzosok és a saját földrajzi társaságuk közti viszonyt. OGILvIE esetében ráadásul az a hálózat személyes, családi elemmel is átitatódott, ugyanis felesége, EvELYN férjéhez hasonlóan Oxfordban végzett geográfus volt, és miután a katonai elhárítás (MI4) átvilágította, belépókártyát kapott az Hôtel Majesticbe. Ezt követően fizetés nélküli asszisztensként a londoni RGS geográfusai (HINKS, 
HoLDICH és a többiek), illetve a Párizsban tevékenykedő férje közti összekötőként látott el feladatokat.

Mindezek a lehetőségek (az 1919 előtti szakmai és személyes kapcsolatrendszer mozgósítása, majd továbbfejlesztése a párizsi munka sajátos tereiben, az etnikai térképezés kibontakozása) természetesen máshogy érintették a magyar geográfusokat. Az APPONYI AlBERT gróf vezette magyar delegáció (amelynek egyik tagjai volt TELEKI PÁL) semmilyen szerepet nem töltött be a béketárgyalásokon 1919. december 1-jéig (hivatalosan 1919. december 3-án fogadták el a tárgyalásokra való meghívást). A küldöttség csak 1920 januárjában érkezett meg Párizsba, addigra Magyarország új határai már kirajzolódtak (ZEIDLER M. 2017b). Az amerikai delegáció hírszerzési csoportja az első hivatalosnak tekinthető tervezetet Magyarország új határairól 1919 januárjában készítette el, az ügyben illetékes szekció vezetője IsAIAH BowmAn volt (DEÁK, F. 1942). Az Amerikában élő, magyar származású diplomáciatörténészt, FRANCIS DEÁKot tájékoztatva BowMAN bepillantást engedett a munka folyamatába. A különböző témákról készített memorandumokat „rövid és megjegyzések nélküli ajánlásokba rendeztük". Ezeket az ajánlásokat további szerkesztés után „összeállítottuk, térképekkel illusztráltuk, és a 'Black Bookban' foglaltuk össze” (DEÁK, F. 1942, p. 27). A fekete kötéséről elkeresztelt „Black Book” lett az Egyesült Államok (valójában BowmAn) javaslata az Új Európáról (SMith, N. 2003; REISSER, W. 2012;). Az alaptérképeket az AGS munkatársai jó előre, a delegáció Párizsba indulása előtt elkészítették (n. n. 1919 - a szerző valószínúleg BowmAN, I. volt). A térképkészítés és a határok kijelölése volt a földrajzosok legfontosabb feladata, mivel a kortársak a térképekben politikai fegyvert is láttak, ,olyan erös eszközt, amelyet különleges, gyakran teljes mértékben politikai célokra lehetett mozgósítani”'(SмITH, N. 2003, p. 147).

\section{A magyar földrajz Nagy-Magyarország mellett}

A magyar földrajztudomány a háború során nem készült tudatosan a békekötésre, az ország területi épsége mellett érvelő első szakértői anyagokat csak az összeomlás küszöbén, 1918 őszén kezdték összeállítani. Ez persze nem jelentette azt, hogy előzmények nélkül vágtak volna bele a munkába. A feladat semmiképpen nem volt új: a földrajz már a 19. század második felében a nemzeti identitást megerősíto, nemzetépítő diszciplínák egyike volt (SzILÁGYi A. 2017). A népszámlálások anyanyelvi adatait használó nemzetiségi statisztika, az erre épülő etnikai térképezés (a nemzetiségi kérdés kiemelt politikai fontossága miatt is) komoly hagyományokkal rendelkezett Magyarországon, és geográfusok nemzedékei dolgoztak ki olyan elméleteket, amelyek Magyarország politikai határainak ,természetes” jellegét hangsúlyozták (HAJdú Z. 1996, KEMÉNYFi 2011, KöSZEGi M.-BotTLik Zs. 2020). Ráadásul nem csak Magyarországon gyúlt a tapasztalat: Európa-szerte készültek nemzetiségi térképek, és a szomszédos Balkán az etnikai térképezés „mintaterületének” számított (DEMETER G. et al. 2015). Valószínúleg ennek a felhalmozott hazai és a nemzetközi tudásnak volt köszönhető, hogy a megkésettség ellenére a magyar geográfusok rövid idő alatt magas minőségű anyagokat tudtak készíteni.

A béke-előkészítés Magyar Földrajzi Társaság fótitkárának, TELEKI PÁLnak az ösztönzésére indult el, és a munkában a statisztikai hivatal és kormány mellett a társaság is fontos szerepet vállalt, elsősorban a statisztikai adatok térképezésében, különösen a nemzetiségi térképek készítésében (HAJDú Z. 2000). Többféle „etnográfiai térkép” készült az összeomlás közepette. A társaság választmánya négy eltéró módszerú térképtervezet közül a Kogutowicz KÁROLY-féle változatot támogatta 1918 októberében, így elsőként az 1:200 000-es méretarányú, részletgazdag térkép készült el (FILEP A. 2010; SEGYEVY 
D. 2016). TeleKi PÁL viszont - miközben az influenzával küzdött 1918 decemberében egy sokkal szuggesztívebb, a magyar álláspontnak jobban megfelelő térképet álmodott meg. Így emlékezett a térkép alapötletének megszületésére egy 1920 januárjában adott interjúban: „A térkép annak köszönheti létrejöttét, hogy amikor a Hadigondozó elnöke voltam, spanyolbeteg lettem....Ez 1918 november végén történt. Ha nem betegszem meg, a Hadigondozóban végzett sok munkám mellett aligha csináltam voltam meg valaha. Így azonban három hétig az ágyat kellett óriznem, és ott érlelödött meg bennem ennek a térképnek az ötlete. Rajztáblával az ölemben csináltam meg a térkép első vázlatait.... Január elejére készen voltunk. A munka hat hetet vett igénybe" (BENDA J. 2017a, p. 75). $\mathrm{Az}$ anyanyelvi adatokat a népsűrúség figyelembevételével ábrázoló ikonikus térképet, a Carte rouge-t TELEKI 1919. január közepén mutatta be a Magyar Földrajzi Társaságban, egyben azt is javasolta, hogy a társaság Magyarország területi épségének védelmében egy manifesztumot fogalmazzon meg (ABLONCZY B. 2018, p. 76).

A Magyar Földrajzi Társaság szózata a világ Földrajzi Társaságaihoz címet viselő tanulmány (MFT 1918) kétségkívül alapvetően TELEKI munkája (FODOR F. 2006,p. 760), és a Földrajzi Közlemények 1918. évi 7-9. füzetében jelent meg, de már az 1919-es esztendőben. A dokumentum fontosságát jelzi, hogy a Párizsba megérkező magyar békedelegáció a „szózat" francia változatát (több más földrajzi anyaggal, térképpel, pl. a Carte rouge-zsal, a Kogutowicz-térkép 1:300000-es változatával együtt) 1920. január 14-én, az ún. Előzetes Jegyzékek között, a II. jegyzék 3. mellékleteként benyújtotta a békekonferenciához (ZEIDLER M. 2017a, p. 263). A bő harminc oldalas szöveg a legfrissebb tájföldrajzi irodalomra támaszkodva foglalt egységes, összefüggő rendszerbe minden olyan fontos földrajzi érvet, amelyeket azután a két világháború közti magyar földrajz fejlesztett tovább a revízió tudományos alátámasztásra. TELEKI már a háború előtt is a francia emberföldrajz híve és magyarországi népszerúsítóje volt, ezért nem véletlen, hogy a tanulmányban a legtöbb hivatkozást a korabeli francia geográfusok kapták. Emellett azonban taktikai megfontolások is a francia elméleti bázis mellett szóltak: a legfontosabb tárgyalófélnek a franciák számítottak, és a magyar földrajzosok abban is bízhattak, hogy a francia alapokra épített érvelés meggyőző bizonyíték lehet Nagy-Magyarország fenntartása mellett. Minden bizonnyal ez is hozzájárult, hogy a manifesztum legtöbbet hivatkozott geográfusa VIDAL DE LA BLACHE lett (KRASZNAi Z. 2012).

A bizonyítás során a magyar geográfusok rendre a természetföldrajzi egység eszméjéből indultak ki. „Minden morfológiai, geológiai vagy tektonikai avagy orográfiai térképen Magyarország mint jól meghatározott kerek egység tünik szemünkbe." - fogalmaz a Magyar Földrajzi Társaság szózata (MFT 1918, p. 292). A Kárpát-medence világos természetföldrajzi választóvonalakkal rendelkező nagytáj, amelyet északon és keleten a Kárpátok koszorúja övez, nyugati határát pedig az Alpok nyúlványai jelölik ki. A déli határ viszont természet-földrajzilag nem ennyire markáns, talán ez magyarázza, hogy a politikai határok is ezen a vidéken voltak a legbizonytalanabbak. A jól kirajzolódó határok nem csak a medence domborzatában öltenek testet, hanem hatásuk az éghajlat, a növény- és az állatvilág egységes jellegében is érvényesül.

A természetföldrajzi egység gondolatát az 1920-as, 1930-as években PRINZ GYULA Tisia-elmélete mélyítette el (KEMÉNYFI R. 2006). Az elmélet szerint a Kárpát-medence mélyén egy ősi, kristályos tömb, a Tisia-masszívum rejtőzik, amely körül mint kaptafa körül gyűrődött fel a Kárpátok. Prinz hangsúlyozta, hogy a természet (vagy a gondviselés) évmilliókkal ezelőtt formálta ki a Kárpát-medencét egy ország tökéletes természeti alapjául, és ezt a földtörténeti időkbe visszanyúló egységet nem tudják megbontani az időleges államhatárok. Igazat kell adnunk a Magyar Földrajzi Társaság szózatának: Nagy-Magyarország határai a korabeli domborzati és geológiai térképeken még akkor is 
szembetűnők, ha ezeken az államhatárok nincsenek feltüntetve, ugyanakkor azt sem szabad elfelejteni, hogy a természetes határok látványos megjelenését a választott ábrázolási technika nagyban elósegítette

Különösen fontos szerepet szántak a magyar geográfusok a természetföldrajzi érvek sorában a vízrajzi egység gondolatának. A Kárpát-medence folyói ugyanis kevés kivételtől eltekintve a Dunába, annak is a történeti Magyarországra eső szakaszába torkollanak. Ez az előnyös hidrográfiai helyzet viszont az új határvonással rendkívül sérülékennyé vált, hiszen a magashegységi vízgyűjtőterületeken végrehajtott beavatkozások (a felszínborítás megváltoztatása, az erdőirtások) növelik az alföldi területeken az árvízveszélyt. Ráadásul a hegyekből induló, gyors lefutású árvizek elleni védekezést megnehezíti, ha az információáramlás előtt új akadályok tornyosulnak. A lehetséges következményeket drámai hangütésben fogalmazta meg a Magyar Földrajzi Társaság szózata: „Az árvízvédelem és hírszolgálat egyszerüen lehetetlenné válnék, ha Magyarország feldaraboltatnék ... mert az ellenségeink követelései alapján felosztott Magyarország Közép-Tiszájának és a szerb Alsó-Tiszájának népét a fenyegetó árvíz-veszedelemröl a Bodrog és Hernád mellól a tót, a Latorca és Tisza mellól a rutén, a Visó, Szamos és Körös mellól az oláh kellene, hogy figyelmeztesse!" (MFT 1918, p. 301.)

Magyarország egységét nem csak természeti földrajzi, hanem számos gazdaságföldrajzi megfontolás is támogatta. A magyar geográfusok a Kárpát-medencét gazdasági termelésükben egymást kölcsönösen kiegészítő tájak harmonikus egységének látták, olyan gazdasági térnek, amely táji sokszínúségének köszönhetően szinte az önellátásra is képes. A gazdasági érvelés a tájföldrajzi hagyománynak megfelelően természetföldrajzi alapokon nyugodott. Leegyszerúsítve úgy lehetne összefoglalni az elmélet lényegét, hogy a Kárpátmedence belső területe, az Alföld, a Kisalföld, a Dunántúl jelentős része domborzati, éghajlati és talajadottságainak köszönhetően a legfontosabb agrártermékekből, különösen kenyérgabonából saját lakosságát messze meghaladó népesség ellátását tudja fedezni, ugyanakkor ezek a tájak fában, ásványkincsekben, energiahordozókban szegények, és ipari nyersanyagok behozatalára szorulnak. Emiatt a hegyvidéki peremterület és a medence síkvidéki középső része között egyfajta természetes munkamegosztás és árucsere alakult ki, amelynek megbontása nemcsak a magyarság, hanem a Kárpát-medence nem magyar ajkú nemzetiségei számára is kifejezetten káros (MFT 1918, pp. 307-310). A két világháború között a gazdaságföldrajz mellett a revíziós propaganda is sokszor visszatért ehhez a gondolathoz, a Magyarországtól elcsatolt hegyvidéki lakosság éhezésének rémképét lefestve.

A természetföldrajzi és gazdaságföldrajzi elgondolásokkal összhangban álltak a településföldrajzi érvek is. A századelő földrajztudománya a városok kialakulásában, a városok térbeli helyének „,kijelölésében” fontos szerepet a tulajdonított a tájhatároknak. Minden egyes táj a saját természeti adottságaihoz alkalmazkodó gazdasági termeléssel rendelkezik, és termékeit a tájhatárokon kialakult vásárvonalakon cseréli ki. Ezeknek a vásárvonalaknak a legenergikusabb, közlekedésileg legjobb helyzetű pontjain alakulnak ki a városok. A Kárpát-medence legmarkánsabb vásárvonala a hegyvidék és a síkvidék határán fut, a városokat pedig a hegyvidékről a folyóvölgyekben, szorosokban kifele futó utak mentén találjuk. Ilyen városok például Erdélyi-középhegység és az Alföld találkozásánál Nagyvárad, Arad vagy az Alpokalja és a Kisalföld határán Sopron. Magyarországon a hegyvidék és a síkság tájhatára sokszor nyelvi, nemzetiségi határ is, maguk a tájhatárra települt városok is gyakran többnyelvúek. Ezért a nyelvhatárhoz igazodó országhatár esetén eldönthetetlen, hogy ezek a városok melyik tájhoz, melyik országhoz tartozzanak. A hosszú idő alatt, szerves fejlődés során kialakult településhálózati rendszerbe történő drasztikus beavatkozás további károkkal is jár - érveltek a magyar geográfusok. Az 
országhatár szélére szorult városok vonzáskörzete féloldalas lesz, ez egyrészt a városok gazdasági stagnálásához, másrészt a központ nélkül maradt, piacukat vesztett falvak sorvadásához vezet (MFT 1918,pp. 307-310).

Magyarország soknyelvúségét természetesen a magyar földrajztudósok nem vitatták, viszont azt vallották, hogy a magyarok és a nemzetiségek közti nyelvhatár nem képezheti egy országhatár alapját. A nyelvhatár ugyanis a legtöbb vidéken nem éles vonal, hanem egy széles, vegyes lakosságú, nyelvszigetekkel tarkított zóna vagy egyes régiókban egyenesen többnemzetiségú falvak övezete. Míg a magyarság zöme egy nagyobb és egy kisebb tömbben él a Kárpát-medencében, addig a nemzetiségi területek felszabdaltak, mozaikosak. Még ott is, ahol a nemzetiségi lakosság többséget alkot (pl. a Felföld északi megyéiben a szlovákok, Erdély és a Partium jelentős területein a románok), a településterületük foltjait rendre lakatlan hegyvidékek szakítják meg. Ezt az álláspontot meggyőző erővel támasztotta alá TELEKI PÁL híres „,néprajzi” térképe, a Carte rouge. A területi integritás megtartását célzó térkép nemcsak az egyes nemzetiségek térképi színének taktikus megválasztásával, hanem a lakatlan területek hangsúlyozásával is törekedett a magyarság súlyának „,vizuális” erősítésére.

A többnyelvú jelmagyarázattal ellátott Carte rouge a magyar nemzeti identitás és Magyarország fenyegetett területi integritásának legfontosabb szimbólumává vált. Nemcsak Magyarországon, hanem külföldön is széles körben ismertté vált, hatása a földrajzos szakmai körökön messze túlterjedt (SEEGEL, S. 2018, pp. 64-66). A magyarok törekedtek is arra, hogy a különböző méretekben, változatokban napvilágot látott térképet minél szélesebb körben terjesszék: a Carte rouge TELEKI és a magyar geográfusok külföldi publikációiban (más térképpel együtt) rendre megjelent (pl. TELEKI P. 1919b, 1919c, 1923; FODOR F. 1920a, 1920b, 1928; n. n. 1920-1922).

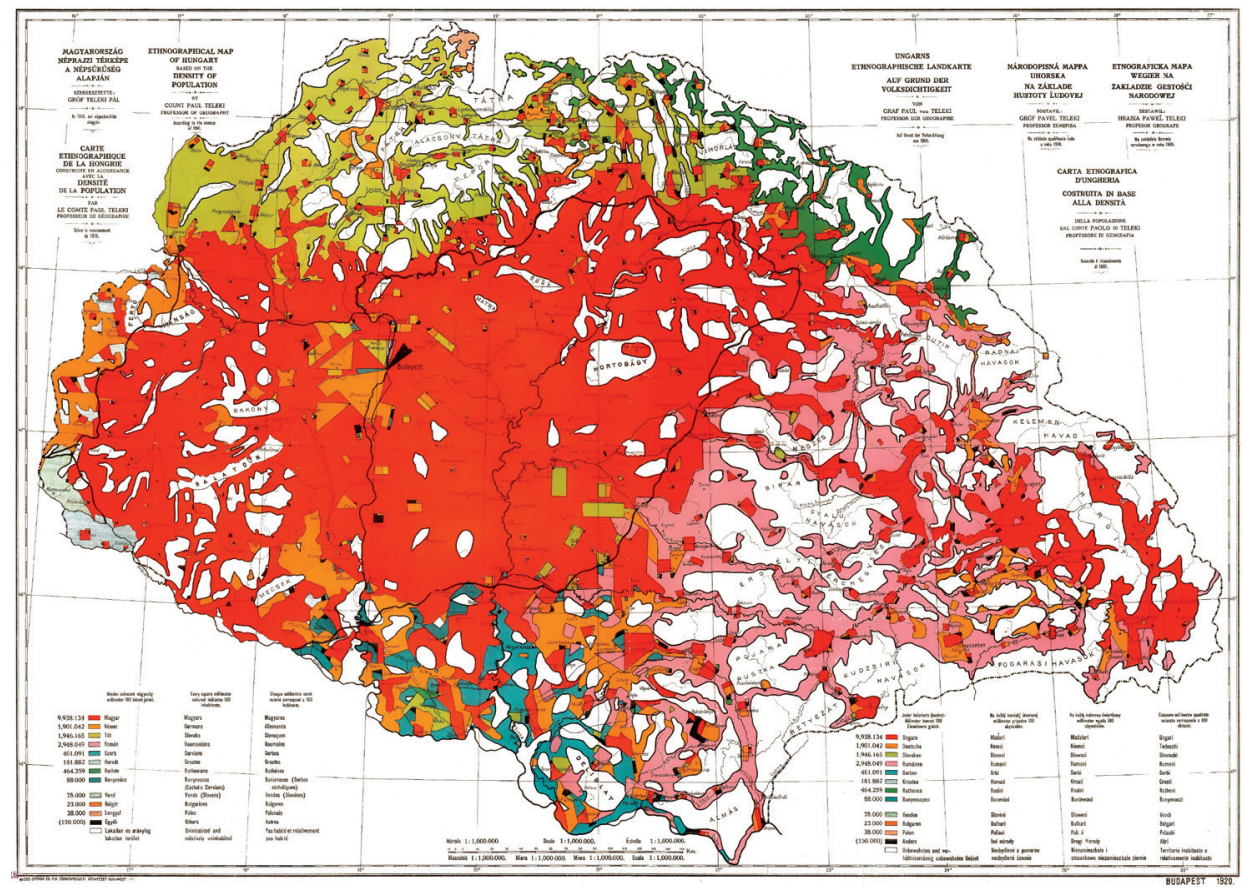

1. ábra Magyarország néprajzi térképe a népsúrúség alapján (szerk. TELEKI P. 1919)

Figure 1 Ethnographical map of Hungary based on density of population (ed. by TELEKI, P. 1919) 
TELEKI és kollégái a nemzetközi szakmai kapcsolatrendszerüket is megpróbálták mozgósítani a magyar ügy érdekében. A CHOLNOKYhoz 1918 november elején írt levelében TELEKI konkrét nevekkel és kiemelt érvekkel ellátott „,cselekvési tervet” küldött a Kolozsváron élő barátjának (TELEKI P. 1918a):

\section{„Kedves Jenö!}

Avval a nagy kérdéssel jövök, hogy hajlandó volnál-e az USA-ba utazni. Én hetek óta dolgozom Kogutowiczzal, Buday Lászlóval stb. stb., országunk függö kérdéseire vonatkozó tudományos anyag elókészítésén. A második feladat az volna, hogy ne csak ez az anyag álljon rendelkezésre, hanem ki is menjenek olyanok, akik az ország viszonyait alaposan ismerikés akiknek odakint jó összeköttetéseik vannak. Az öreg [Lóczy Lajos - GyR megj.], tekintettel arra, hogy Scott Keltie-vel és másokkal jól van, oda menne ki. A fenti másik vonatkozásban mindketten Rád gondoltunk, és proponáltalak is. Az a kérdés, vajjon ezekben a zavaros viszonyokban Te vállalkoznál-e egyáltalán elhagyni az országot? Kérlek, tudass erról minél gyorsabban.

Ezen kívïl arra kérnélek, hogy írjál egynéhány levelet azoknak, akikkel az entente országaiban jól vagy, óket felvilágosítva a viszonyokról. Nekem lesz alkalmam, hogy ezeket valamelyik módon kijuttassam. Mit gondolsz, de Martonne milyen álláspontot fog elfoglalni? Írjunk neki?

Ezen leveleken kívül nagyon jó volna, ha elsósorban magad, esetleg azonban mások is, talán Schilling is, talán más egyetemi tanárok is írnátok cikkeket, amelyeket szintén kijuttatnék, és amelyek kétfélék lehetnének, egyik részük saját aláirással jelenhetne meg, a másik olyan anyagcikk-féle lehetne, azt értem ez alatt, hogy olyan cikk, amelyeknek egész tartalmát és gondolatmenetét egy odaki való ember, például svájci felhasználhatja, ir hozzá bevezetést és konklúziót, átstilizálja a maga stílusa szerint, és az oo neve alatt hozza ki. Ezeket most volna legföbb ideje elhelyezni. Igen jó volna, ha jól összefoglalva és kelló pontos részletességgel kidomborítanád, azt a kérdést, hogy egy ország, amelyiktól elveszik összes vasát, szenét, fáját és nemes érceit, vajjon nem melegágya-e egy új gazdasági háborúnak, éppen úgy, mint egy új irredentának a tólünk elszakadó négymillió magyar.

Örülnék egyáltalán hallani Rólad és az állapotokról odalent, felfogásodról magyar és oláh körökben. Itt a nyugalom külsóleg teljesen helyreállott. Rend van, közlekedés és kereskedelem zavartalan, tisztán csak az bizonytalan, hogy a jövó mit hoz, és legföképpen csak az a kérdés, hogy lesz-e elég szén. Írjál minél elóbb, és segíts a fenti dolgokban.

\section{Szívböl ölel,}

Pali"

TELEKI az amerikai és brit kollégákhoz fordult. December végén írt ISAIAH BowMANnek (akivel az 1912-es amerikai transzkontinentális utazáson személyesen is találkozott), és ebben a levelében ugyanazokat az érveket fejtette ki, amelyeket CHOLNOKYnak javasolt hetekkel korábban (TELEKI P. 1918b). A néhány nappal később JOHN SCOTT KeLTIE-nek küldött levelét (és annak részeletes mellékletét) a brit Foreign Office szakértői „,már kézbesítés előtt" átvizsgálták. TELEKI az MFT footitkáraként szólította meg KELTIE-t, az RGS korábbi főtitkárát (aki annak idején az RGS tagságára ajánlotta magyar kollégáját), és abban kérte támogatását, hogy „, a magyar kérdést Kelet-Közép-Európa jövoóje érdekében tudományos alapossággal tanulmányozzák, mert ha az összes elképesztó igény teljesülne, akkor Magyarország az új Macedóniává válna”. Teleki azt javasolta, hogy a probléma alapos megismerésére komoly szaktekintélyeket küldjenek Magyarországra, akik „az 
adatainkat is tudják majd a helyszínen igazolni ... Az angolok azok, akik ezt leginkább pártatlanul tehetik meg" (TELEKI P. 1919a). KeLTIE az RGS hivatalban lévő főtitkárával HinKS-szel egyeztetett, és javasolta, hogy a Foreign Office-nak továbbítsák az anyagot (Keltie, J. S. 1919b). Hinks igyekezett rövidre zárni ezt az epizódot: „Nem hiszem, hogy Telekinek levelet kellene küldenünk, és azt gondolom, hogy semmi esetre sem szabadna az ellenséggel kommunikálnunk" (HINKS, A. 1919). TELEKI a január eleji levelében utalt arra, hogy Lóczy KELTIE-nek írt levele is úton van már. Sajnos ez a dokumentum nem található meg RGS levéltárában, de létezését KELTIE HiNKS-nek küldött levele bizonyítja, amelyben meleg szavakkal, jó ismerőseként írt LócZYról (KeLTIE, J. S. 1919a). Végül LócZY levele is a Foreign Office-nál kötött ki. A háború végi időkből nincs az RGS levéltárában anyag CHOLNOKY JENŐtôl, csak néhány évvel későbbről van bizonyítékunk CHOLNOKY és George Goudie Chisholm közti levelezésre (Chisholm, G. G. 1924; az edinburghi-i geográfus és CHOLNOKY még az 1912-es transzkontinentális utazáson ismerték meg egymást.). CHISHOLM a naplójában nem tesz említést trianoni kérdésrôl, viszont az egyetemi előadásaihoz készített jegyzetekből kiderül, hogy erősen foglalkoztatták a ,versailles- $i$ béke" kérdései és az „osztrák-magyar erôforrások” háború utáni hanyatlása (CHISHOLM, G. G. 1919).

A háborús vereség, az Osztrák-Magyar Monarchia összeomlása után Magyarországon a politikai instabilitás hosszú hónapjai következtek. Az őszirózsás forradalom, a Tanácsköztársaság, a román megszállás hátráltatták a béke-előkészítést: 1919 tavaszától a nagy lendülettel megkezdett szakmai munka is szünetelt. A Béke-előkészítő Irodát hivatalosan csak 1919 augusztusában állították fel, a szervezetnek TELEKI állt az élére (ZEIDLER M. 2017b). CHOLNOKY a munkáját TELEKI helyetteseként kezdte, majd később ő lett a vezetője az iroda átszervezése után a Külügyminisztérium Tudományos Osztályává vált intézménynek. A béke-előkészítés újraindítása nem volt egyszerú feladat. CHOLNOKY 1905 óta a Kolozsvári Egyetem földrajzprofesszora volt, a háború vége az erdélyi városban érte. Miután nem tette le a húségesküt, ezért kiutasították Romániából: pár napos rendőrségi fogda után 1919. október elején tudott elindulni Budapestre (CHOLNOKY J. 1998, pp. 272-273). Talán még ennél is kalandosabban lett a Béke-előkészítő Iroda munkatársa FoDOR FERENC, aki 1912-től a karánsebesi gimnáziumban tanított. Feleségével együtt ők sem tették le a hűségesküt, ezért mindkettőjüket felfüggesztették az állásukból. Önéletírásából nemcsak a Budapestre eljutás kalandjairól, hanem a Béke-előkészítő Iroda múködésének nehézségeiről is képet kaphatunk (FODOR F. 2016, pp. 323-324).

„Én mindent elkövettem, hogy feljuthassak Budapestre. Szeptember 24-töl október 5-ig jártam utána, hogy a megszálló oláh katonaság engedélyt adjon erre. De a Tiszán senkit sem akartak átengedni. Végül is elhatároztam, hogy szökve megyek át. Október 6-án vonattal eljutottam Szajolig. Itt kiszálltam, s táskámat a vonatban egy becsületes képú vasutasra biztam, s azután az oláh katonák által már megvizsgált kocsiba ügyesen ismét visszaszöktem. Így jutottam át a Tiszán. Éjjel érkeztem Budapestre. ... Azután a közoktatásügyi minisztériumban jelentkeztem, és szolgálati beosztást kértem. Be is osztottak a Szabadoktatási Tanácshoz, de közben Teleki Pálnál járva, ö azonnal beosztott a külügyminisztérium Béke-elókészító Irodájába, amelynek ő volt a vezetôje. ...

Új beosztásom közvetlenül Teleki Pál munkatársává tett. Fóleg a béketárgyalásokhoz. szükséges térképek készítése, azoknak a Magyar Földrajzi Intézetben való sokszorositásának irányítása volt a feladatom. Munkaköröm nagyon érdekes és nagyon változatos volt, de nem veszélytelen, mert Budapest oláh megszállás alatt volt, s ilyesmivel foglalkozni nem lehetett. Irodánk a királyi palota északnyugati szárnyának második emeletén volt. Velem egy helyiségben dolgozott Ezry Sándor, Teleki Pál személyi titkára, akiról késóbb kitünt, hogy az oláhoknak kémkedett, továbbá Kristóffy József, aki a második világhábo- 
rú elött oroszországi követünk lett. Sok érdekes és nagynevú emberrel kerültem itt kapcsolatba, pl. Apponyi Albert, gr. Bethlen István, s együtt dolgoztam Kovács Alajossal, a Statisztikai Hivatal elnökével és még sok mással.

Helyzetem türhetö volt. Délben a külügyminisztérium étkezöjében ebédeltem én is, az elképzelhetó legszúkösebb módon. Koldusszegény volt mindenki. Ruházatom igen gyenge állapotban volt, felöltöm még Karánsebesen készült a háború végén egy elviselt és lefutott katonaköpenyböl, de ekkor mindenki rongyos volt. Legnagyobb gondom az volt, hogy családomtól október végétól kezdve teljesen el voltam zárva, mert az oláhok a Tiszán át még a postát sem engedték keresztül. Jól kerestem, mert tanári fizetésem mellett még pótlékot is kaptam a Béke-elókészitö Irodától, de családomnak semmit sem tudtam eljuttatni, holott tudtam, hogy nélkülöznek."

1918-1919 zúrzavaros időszakában az országot nem hívták meg a békekonferenciára a kaotikus állapotok miatt. Magyarország képviselői különleges körülmények közé érkeztek meg 1920 januárjában Párizsba: túl későn ahhoz, hogy beleszólásuk legyen a határozatokba, amelyeknek javaslatait már addigra elfogadták, és a határokat ábrázoló térképek vázlatait is elkészítették. A magyar küldöttségnek nem volt lehetósége változásokat kicsikarni: egy olyan ország képviselői voltak, aminek ,földrajzát” már gyökeresen átrajzolták. Azzal is szembesülniük kellett, a nagyhatalmak számára a „magyar kérdés” nem volt lényeges. A magyarokat már régóta az Osztrák-Magyar Monarchia privilegizált nemzetének tartották, sőt Párizsban egyenesen a többi nemzetiség elnyomóit látták bennük.

Nemcsak a vesztes, hanem győztes nemzetek is kifáradtak a hosszú háború végére, és 1920 tavaszára a győztesek képviselőinek már a békekötés munkájából is elegük volt. Legtöbbjüknek a német békeszerződés megfelelő kialakítása volt a célja. Ez a békeszerződés pedig semmilyen formában nem érintette Magyarországot. FRANCIS DEÁK szerint a magyarokkal szembeni ellenszenv „, a béketárgyalás sok résztvevójének döntően befolyásolta az érzelmeit, akik ráadásul elsósorban Németország ügyeit tartották fontosnak. Amint a német békekötés megtörtént, csakfelületes érdeklödést mutattak a többi békeszerzoodésnél" (DEÁK, F. 1942, p. 181). Mások azt emelik ki, hogy a trianoni békeszerződésen már „csak túl akartak esni” a hosszúra nyúlt tárgyalásokon, ,ez idő tájt a döntéshozók fö törekvése már az volt, hogy mielöbb lezárják az ügyeket”' (CAPLES, M. 2005, p. 55). „Magyarország szemben a puszta közömbösség nyilvánult meg” (MACMILLAN, M. 2001, p. 277). TELEKI PÁL frappánsan számszerúsítette is ezt a közömbösséget még a magyar békeszerződés aláírása előtt adott interjúban: „,ennek a békének fontosságában 80 százalékát teszi ki a német béke, a másik négy béke együttvéve adja a többi húsz százalékot. Az osztrák, bolgár, török, magyar béke közül is az antantot a törökkérdés érdekli a legjobban, úgy, hogy a magyar békére nem esik több, mint mondjuk négy százalék" (BENDA J. 2017b, p. 193).

A magyaroknak sikerült ugyan néhány döntéshozóban rokonszenvet felébreszteni, de ez nem vezetett a határozatok megváltoztatásához. APPONYI 1920. január 16-i beszéde az olasz miniszterelnökre, FRANCESCO NiTTIre gyakorolta a legmélyebb hatás, de még LLOYD GEORGE, brit miniszterelnök reakciói is bíztatónak tûntek - legalábbis a magyar delegátusok benyomásai szerint (RoMSICS I. 2001, pp. 175-177). APPONYI a Carte rouge-t is kiterítette a tárgyalóasztalra, és a térkép szintén komoly érdeklődést váltott ki (MACMILLAN, M. 2001, p. 277). Magyarország új határait viszont nem módosították a magyar delegáció érveinek hatására.

A Nagy-Magyarország melletti érvek és a földrajzi érvrendszer továbbfejlesztése, bel- és külföldi népszerúsítése a békeszerződés aláírása után is folytatódott. Nemcsak a Carte rouge jelent meg sokféle kiadványban, hanem sok más innovatív elmélet, újszerú kartográfiai ábrázolás is napvilágot látott (KEMÉNYFI R. 2010, GYURIS F. 2014). Számos 
anyag született az angol nyelvű közvélemény tájékoztatására, emellett Nagy-Britanniában és Amerikában is akadt pártfogója a magyar ügynek (PETERECZ Z. 2017). A „Justice for Hungary" kampány az 1920-as évek végén erősödött meg, amikor - Olaszország támogatását megszerezve - Magyarország külpolitikai elszigeteltsége oldódott. A megjelent angol nyelvú kötetek (pl. APPONYI A. 1928, LÉGRÁDY O. 1930) szuggesztíven mutatták be a földrajzi érvrendszert; előbbi földrajzi fejezetét FoDOR FERENC írta. Talán az egyik leglátványosabb kartográfiai ábrázolás az volt, amely a magyar területi veszteségek nagyságát más országok területén mutatta be. Készült ilyen összehasonlító térkép Nagy-Britannia, Franciaország, Olaszország, Németország és az Egyesült Államok területére; a LÉGRÁDY testvérek angol nyelvű revíziós albuma a könyv legelejére, az előszó elé helyezte el brit térképet.

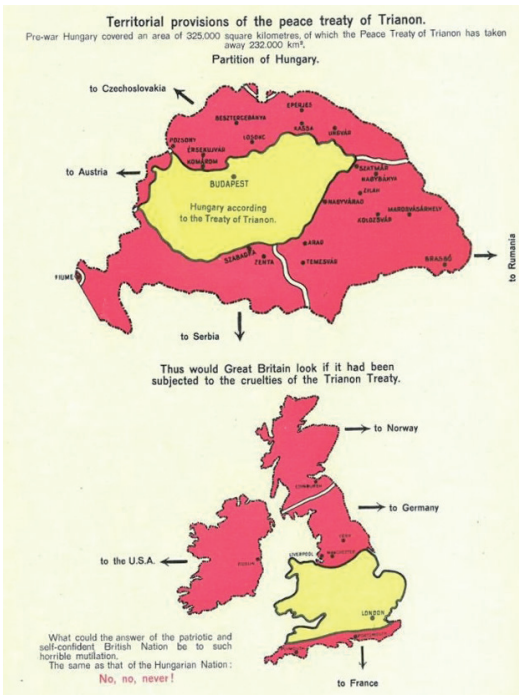

2. ábra Trianon kegyetlensége más országokra alkalmazva. Forrás: LÉGRÁdY O. 1930. Figure 2 Territorial provisions of the peace treaty of Trianon. Source: LÉGRÁDY, O. 1930.

A területi revíziós célok mértékét illetően Magyarországon többféle vélemény fogalmazódott meg (ZEIDLER M. 2009, pp. 81-90). A területi revízió minimális célját jelentette a vitathatatlanul magyar lakosságú, az új országhatárok túloldalán fekvő területek visszacsatolása, illetve a távolabbi magyar nyelvszigetek számára az autonómia megszerzése. A hivatalos magyar külpolitika és a külföldre irányuló propaganda ezt az álláspontot képviselte 1920-as években. Az ún. „optimális revízió” szintén a döntően magyarlakta területek visszacsatolására irányult, de ezeket a területeket gazdaságföldrajzi, regionális földrajzi szempontok figyelembevételével igyekezett kikerekíteni. A legnagyobb belső támogatottsággal az integrális revízió (Mindent vissza!) gondolata rendelkezett, amit a hazai közvélemény előtt a magyar kormány többek között az oktatáspolitikában és a propagandatevékenységben is képviselt. A magyar geográfusok túlnyomó része is a teljes revízió mellett foglalt állást, aminek megvalósítása azonban az 1920-es években szinte lehetetlennek látszott.

Ezért tekinthető kivételesnek KoguTowiCz KÁROLYnak, a Szegedi Egyetem Földrajzi Intézete igazgatójának 1927-ben publikált térképe. Míg a Carte rouge-nak az volt az üzenete, hogy Nagy-Magyarország feloszthatatlan, a nemzetiségi keveredés miatt lehetetlen etnikai határokat meghúzni, addig KoGUTOWICznak a nagyközönségnek, a magyar közép- 
osztálynak szánt térképe ezzel szemben az etnikai felosztás lehetősége mellett érvelt. A Carte rouge és a KoguTowicz 1927-es térképe között sok a hasonlóság, de még több különbség fedezhető fel. Minkét térkép szinte ugyanazokkal a színekkel dolgozott: a vizuálisan domináns vörös szín (mint minden korabeli magyar térképen) a magyarokat jelölte. A magyar nyelvterületen belül, illetve annak peremén elhelyezkedő német közösségek a narancssárga színt kapták, így első látásra egybeolvadtak a magyarokkal, vizuálisan növelve az utóbbiak súlyát, míg pl. a románokat egy jellegtelen szürkés-lilás árnyalattal tüntették fel. Lényeges különbség ugyanakkor, hogy Teleki térképe fehér színnel ábrázolta a lakatlan területeket, így egyrészt jól kirajzolódott a Kárpátok „természetes határa”, másrészt pedig a periférikus, alacsony népsúrűségú nemzetiségi területek érzékelhető súlya kisebb lett. KoGUTOWICZ térképe ezzel szemben nem ábrázolt lakatlan területeket, így a nemzetiségi területek súlya megnövekedett, az egyes etnikai csoportok éles határokkal (nem pedig lakatlan területekkel vagy kevert zónákkal) váltak el egymástól. Hogy a magyarok számára legfontosabb etnikai határokat még jobban kiemelje, a két nagy magyar tömböt vastag vörös vonallal határolta körül.

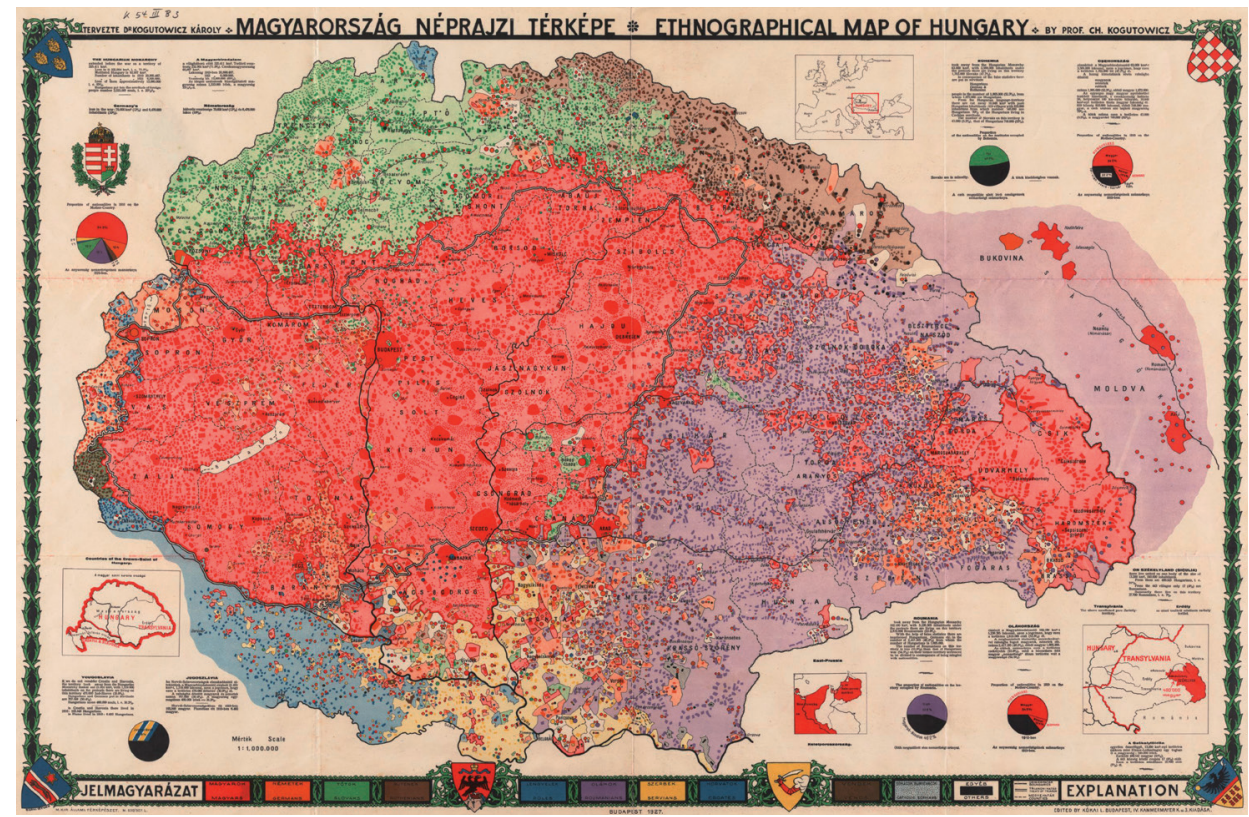

3. ábra Magyarország néprajzi térképe (szerk. Kogutowicz K. 1927)

Figure 3 Ethnographical map of Hungary (ed. by Kogutowicz, K. 1927)

KoGUTOWICZnak a térképhez írt magyarázója világossá tette az újszerű eljárás célját, az „etnográfiai alapon valamivel igazságosabb határok” elérését is, mivel „,örténeti jogaink elismertetésének és a teljes integritás helyreállitásának az ideje még nem érkezett el" (p. 1). Bár ez a cél egybeesett a külpolitikai realitásokkal és a magyar diplomácia korabeli törekvéseivel, a magyar közvélemény (és a geográfus közösség) számára vállalhatatlanul kevés volt. Annak ellenére, hogy az etnikai revíziót KoguTowiCz is csak átmeneti megoldásként képzelte el, munkájának a fogadtatása egészen húvös volt, amit FODOR FERENC (2006) így jellemzett két évtizeddel később: „,[KogUTOwICZ] 1927-ben bocsátotta ki új módszerú magyar néprajzi térképét, ami igen heves ellentmondásokat és erös földrajzi 
kritikát váltott ki. Ettól kezdve a fövárosi geográfiai körökkel való érintkezése csaknem egészen megszakadt" (pp. 647-648).

Ebben a kétrészes tanulmányunkban nem vállalkozunk arra, hogy az 1920-as, 1930as évek revíziós elképzeléseinek visszhangját a két világháború közti brit földrajzban teljes körúen feltárjuk, hiszen munkánk középpontjában a világháborút követő évek állnak. Tanulmányunk első részének lezárásaként két olyan brit kötetet választottunk ki részletesebb elemzésre, amelyek közvetlenül a békekötés után jelentek meg, és a radikális változások nyomán kirajzolódó új Európát mutatják be.

\section{Newbigin és Ogilvie könyvei az új Európáról}

A magyar kortársaival ellentétben MARION NEWBIGINnek az I. világháborút lezáró békekötések „,nem teremtették meg az új világot.” „Éppen ellenkezóleg”-írta,-, ,ez a békekötés a régi idók konfliktusainak szellemében fogant" (NEWBIGIN, M. 1920, p. 14). Könyvének az elején az összetett, bonyolult helyzetre mutat rá: „A békeszerződések során beállott államhatár és államterület-változások olyan sokfélék és komplikáltak, hogy a tisztán földrajzi osztályozásuk értelmetlen” (p. 5). A tíz fejezetből álló könyvében „Magyarország feldarabolása" Csehszlovákia elemzésével együtt az ötödik fejezetben kapott helyett.

A könyv (Newbigin, M. 1920; a továbbiakban: az Aftermath) lényegében egy politikai földrajzi összefoglalás: minden országot az új határai között mutat be a szerző. Hivatkozások és az eredeti forrásokra utaló jegyzetek hiányában az Aftermath kutatási megalapozása bizonytalan. Szerzője korábban a Balkánról publikált (NewBigin, M. 1915a, 1915b), és 1918-ban főszerkesztôként írt (szerzői névvel meg nem jelölt) cikket a fegyverszünetről (n. n. 1918). A kötetében HinKS-et és Holdich-ot említi, de nem tesz utalást a magyar földrajzosok múveire. NEWBIGIN mindenesetre világosan értette Nagy-Magyarország államhatárai és a természetes határok közti egybeesést, és az etnikai elvet, ami alapján a Trianoni utáni Magyarország kirajzolódott: ,ha egy hagyományos térkép alapján az a benyomásunk támad, hogy a régi királyság természetes egység volt, akkor egy néprajzi térkép ezt az érzésünket illuzórikussá teszi (p. 58). Nemcsak azért teszi illuzórikussá, mert a természetes határok nem egyenlők a politikaiakkal, hanem azért is, mert az etnikai különbségek mögött mélyebb társadalmi különbségek is meghúzódtak. A magyarok fölényben voltak a többi nemzetiséggel szemben, és ,,folyamatos nyomás alatt próbálták magyarosítani óket” (p. 59). Magyarország etnikai alapú felosztását „,nyugati hatalmak diktálták”, akik viszont nem voltak tisztában a társadalmi dimenziókkal. A „nemzetiségi elv alkalmazásának” - az etnikai alapon történő területi felosztásnak - „valóban volt valami logikai alapja" (p. 88), de a szociális kérdések megoldatlansága hosszabb távon is gondot jelenthet.

Azt mondhatjuk, hogy az Aftermath leírása az új Európáról viszonylag szúkös értelmezési keretek között mozog. NEwBIGIN úgy interpretálta Magyarországnak a medence belsejére történő összezsugorítását, hogy az megfelelt a magyar nemzetiségúek térbeli elhelyezkedésének, és azok a területek, amelyeket Trianonban Magyarországnak fel kellett adni, korábban a nemzetiségi elnyomás térségei voltak. Ez az elnyomás számára sokkal inkább szociális és nem annyira etnikai kérdést jelentett, aminek megoldatlansága a jövőre nézve továbbra is veszélyeket rejtett magában. „Nagyon valószínütlen, hogy történeti Magyarország határai között az etnikai feszültségek súlyosabbak lettek volna a gazdasági és a szociális problémáknál, bármennyire is fontosnak tüntek a felszínen az elóbbiek" (p. 63).

NEwBIGINnel ellentétben OGILVIE a helyszínen vett részt a békekötés munkáiban, így a Some aspects of boundary settlement... (1922) sokkal gazdagabb azoknak az alapelvek- 
nek és technikáknak a részletes bemutatásában, amelyek segítségével Európa új határait megrajzolták. OGILVIE 32 oldalas pamfletjét a Society for Promoting Christian Knowledge adta ki, és HAROLD TEMPERLEy lektorálta. A munka bevezetésében OGILVIE azt írta, hogy „ez a kötet segédanyag a versailles-i, St. Germain-i, trianoni és neuilly-i békekötés tanulmányozásához, és a békeszerzódések területi határozataival együtt érdemes olvasni" (p. iii). Ez minden bizonnyal rejtett utalás TEMPERLEY sokkötetes munkájára (1920), ami a világháborút lezáró békeszerződések történetéről született. OGILVIE könyvét a földrajzi szempontok kiemelésével kezdi (pp. 4-5): „A békekonferencia területi döntéseit megalapozó megfontolások földrajzi jellegéról szélesebb és szúkebb értelemben is beszélhetünk. Az adott területen élö népesség egyik államtól a másikhoz csatolásával mindenekelött az országok etnikai sokszínüségét akarták csökkenteni, másodsorban pedig olyan határok meghúzására törekedtek, amelyek az új államok számára a külső és a belsó kommunikációt, közlekedést lehetôvé teszik, amelyek nem válnak azonnal katonai feszültségek forrásává, és amelyek az érintett népesség gazdasági életét a lehetô legkevésbé érintik - hacsak nem teszik a határ mindkét oldalán egyenesen jobbá ... A békekonferencián a 'földrajzi' megjelölést hivatalosan a szükebb értelmében használták, és 'topográfiait' értettek rajta. A Central Geographical Committee létrehozásának két oka volt. Egyrészt ennek a bizottságnak kellett gondoskodnia arról, hogy a kijelölt államhatárok egyszerüen meghúzhatók és könnyen fenntarthatók legyenek, és kitüzésük se ütközzön nehézségekbe, másrészt pedig határmegállapító bizottságok számára kellett instrukciókat elókészíteniük”.

OGILVIE szavai azt sugallják, hogy ezek az alapelvek az összes Párizs környékén megkötött békeszerződésre igazak. De később maga is felhívta a figyelmet arra, hogy ezeknek és más alapelveknek az alkalmazása nehézségekbe ütközött a különböző nemzeti delegációk eltérô érdekérvényesítő képessége miatt. Szerinte a szövetséges és társult hatalmak teljesen elutasították, hogy a magyar delegáció által megfogalmazott etnikai és földrajzi kérdéseket vitára tűzzék. Úgy véli, a legtöbb szakértő egyetértett volna abban, hogy a ,jó határ” eléréséhez több szempontot kellene figyelembe venni: a lehető legtöbb „saját” nemzetiségú embert kellene az új államhatárokon belül elhelyezni, és a lehető legkevesebb „,nem saját” nemzetiségút; törekedni kellene arra, hogy meglévő adminisztratív határokat ne vágják át az új határok; figyelembe kellene venni a helyi sajátosságokat; el kellene kerülni a határvonal éles kiszögelléseit és beugrásait; ha lehet, akkor követni kell a jól megfogható természetes határokat; a lehető legjobb körülményeket kell megteremteni a gazdasági élet múködéséhez; és kerülni kell, hogy meglévő kommunikációs és közlekedési vonalak megszakadjanak.

Könyve második fejezetében rámutatott arra, hogy „az osztrák, a magyar és a bolgár békeszerzódéseknél" ezek a kiemelt szempontok nemcsak a földrajzi körülmények miatt sérültek, hanem az ,haute politique” miatt is, mivel „az alapelveket csak homályosan és általános értelemben fogalmazták meg" (p. 7). Csehszlovákia esetében például a Csehországtól Kárpátaljáig húzódó új állam ,folyamatosan elkeskenyedő alakja a hegyvonulatok futását követte", gazdasági, politikai és stratégiai megfontolásokból itt a békekonferencia ,jobbára eltekintett az etnikai határnak államhatárként való alkalmazásától" (pp. 12, 14). A Magyarország és Jugoszlávia közti új határ meghúzása „,különösen nehéznek bizonyult”. Ugyanez volt helyzet a román határ, a ,nemzetiségek különleges mozaikja” esetében is (p. 21). A fejezetben kiemelte, hogy Magyarország etnikai sokszínúsége miatt az új határ megvonása nagyon problematikus volt. Bármelyik határszakaszt is elemezte, legyen az a jugoszláv vagy a román határ, véleménye egyforma volt: az új államok ,nagyszámú 'nem saját' nemzetiséget kebeleztek be" (p. 23). A baranyai, a bácskai és a bánáti határszakaszt inkább kompromisszumos megoldásnak tekintette, de a javasolt román-magyar 
határt „vitathatónak” nevezte (p. 25), és kiemelte, hogy túl nagy jelentőséget tulajdonítottak a vasúti összeköttetéseknek: „a vasúti kérdések rátelepedtek a döntés egészére” (p. 26). Az Ausztria és Magyarország közti új határ viszont ,elsősorban etnikai és csak másodsorban gazdasági" megfontolások eredményeként született meg (p. 28). Románia új határainál a francia geográfus, EMMANUEL DE MARTONNE elgondolásai érvényesültek, aki a román nemzetiségi szempontokat tekintette elsődlegesnek (PALSKY, G. 2002).

OGILVIE értékelését összefoglalva azt lehet mondani, hogy a hivatalosan megfogalmazott alapelvek már az alapvető földrajzi tényezők miatt is módosultak, és tovább sérültek a határmegvonás egyéb (etnikai, domborzati, közlekedésföldrajzi) szempontjai miatt. OgILVIE és NewBIGIN egyetértettek abban, hogy végeredményben a trianoni határok egyáltalán nem tükrözték a békekonferencia kiinduló szempontjait, és nem feleltek meg WILSON elvének a nemzetek önrendelkezéséről. Az amerikai küldöttségen belül is nézetkülönbségek voltak abban, hogyan dolgozzon a delegáció, milyen szerepet szánjanak az etnikai térképeknek LANSING R. 1921; GELFAND, L. 1963); különösen az amerikaiak vallották, hogy az Osztrák-Magyar Monarchia ,darabokra hullása miatt” Magyarország már soha nem lesz régi önmaga (LANsing, R. 1921, p. 224). Maga BowmAn, I. (1921, p. 218) egész egyszerúen ezt írta: „Az új Magyarország valóban problematikus”. OGILviE és BowmAN egyaránt részt vettek a párizsi tárgyalások szakmai munkájában, és nagyjából egy időben publikálták a béketárgyalásokat, annak földrajzi kérdéseit és az új Európát bemutató munkájukat, ezért érdemes lenne összevetni OGILVIE 1922-es könyvét BowMAN szinte ugyanakkor (1921) megjelent, az új világrendről szóló kötetével. Mivel tanulmányunk mindenekelőtt a brit földrajzosok véleményével foglalkozik, ezért mi itt erre a részletes összehasonlításra nem vállalkozunk.

\section{Összefoglalás}

Kétrészes tanulmányunk fó célja az, hogy feltárja a brit geográfusoknak a párizsi békekötés, illetve a trianoni békeszerződés szakmai előkészítésében játszott szerepét, és tisztázza a Magyarországgal és az új magyar határokkal kapcsolatos álláspontjukat. Tanulmányunk első részét a békekötés helyszínén, Párizsban dolgozó geográfusok bemutatásával nyitottuk. Rövid áttekintésünkből kiderül, hogy a különböző országokat képviselő földrajztudósok jól ismerték egymást, hiszen mindannyian tagjai voltak a múlt századelő élénk nemzetközi tudományos kapcsolatrendszerének. Ezt a meglévő kapcsolati hálót mindenki igyekezett a maga érdekében mozgósítani, így a magyar geográfusok is próbálták megkeresni azokat a befolyásos külföldi kollégákat, akiknek támogatását remélték. A magyar földrajz statisztikai anyagokkal, szuggesztív térképekkel alátámasztott komplex érvrendszert épített fel Magyarország egységének védelmében a világháború végén. Ezek az eszközök azonban nem tudták érdemben befolyásolni az új határok kialakítását. A békeszerződés aláírása után a munka folytatódott: a revízió földrajzi érveinek finomítása és külföldi népszerúsítése a geográfusok fontos törekvése volt. Az első tanulmányunk zárásaként az európai határok átrendezéséról született legrészletesebb kortárs brit földrajzi értekezéseket, MARION NEWBIGIN (1920) és ALAN OGILVIE (1922) köteteit elemeztük. Egyikük sem volt pozitív irányban elfogult a magyarok iránt, és kritikusan írtak a háború előtti magyar nemzetiségi politikáról, de egyetértettek abban, hogy a trianoni határok végül egyáltalán nem tükrözték a békekonferencia kiinduló szempontjait, és nem feleltek meg wilsoni elveknek. Tanulmányunk második részében mutatjuk majd be részletesen, hogyan formálódott ki a háború alatt a brit földrajzosok álláspontja a „magyar kérdésról”, és milyen munkát végzett Párizsban a brit geográfus szakértői csoport. 


\section{Köszönetnyilvánítás}

A kutatás lefolytatását a Magyar Tudományos Akadémia és a Royal Society of Edinburgh Kétoldalú Nemzetközi Együttmúködése tette lehetővé. GYôRI RóBERT kutatásait az NKFIH K 125001 projektje támogatta. A szerzők szeretnének köszönetet mondani American Geographical Society munkatársainak, hogy elérhetővé tették BowMAN ÉS OGILviE levelezését, továbbá EuGENE RAE-nek, a Royal Geographical Society (with IBG) (London) levéltárosának és a Magyar Földrajzi Múzeum (Érd) munkatársainak a levéltári anyagok kutatásában nyújtott segítségükért. Külön szeretnénk megköszönni a néhai ElsPeth Collins-nak, Alan OgILVIE unokájának, hogy Alan OgILviE-nek és a feleségének a naplóit rendelkezésünkre bocsájtotta, majd ezeket a forrásokat elhelyezte a University of Edinburgh Library, Centre for Research Collections-ben.

\section{GYŐRI RÓBERT}

ELTE TTK FFI Társadalom- és Gazdaságföldrajzi Tanszék, Budapest

„Trianon 100” MTA-Lendület Kutatócsoport, Budapest

gyorirobert@caesar.elte.hu

Charles W. J. Withers

University of Edinburgh, School of Geosciences, Institute of Geography, Edinburgh

c.w.j.withers@ed.ac.uk

\section{IRODALOM}

Ablonczy B. 2018: A miniszterelnök élete és halála - Teleki Pál (1879-1941). - Jaffa Kiadó, Budapest. 317 p.

ACKERMAN, E. 1945: Geographic training, wartime research, and immediate professional objectives. - Annals of the Association of American Geographers 35. pp. 121-143.

APPONYI A. (szerk.) 1928: Justice for Hungary: Review and criticism of the effect of the Treaty of Trianon. - Longmans, Green and Co., London. 376 p.

Balchin, W. 1987: United Kingdom geographers in the Second World War: A report. - The Geographical Journal 153. pp. 159-180.

BENDA J. 2017a: Interjú Teleki Pállal, 1920. január 17. - In: ZEIDLER M. (szerk.): A magyar békeküldöttség naplója, Neuilly-Versailles-Budapest (1920). MTA BTK Történettudományi Intézet, Budapest. p. 75.

BENDA J. 2017b: A magyar béke kilátásai. (Interjú Teleki Pállal a magyar békekilátásokról), 1920. március 31. - In: ZeIDLER M. (szerk.): A magyar békeküldöttség naplója, Neuilly - Versailles - Budapest (1920). MTA BTK Történettudományi Intézet, Budapest. p. 193.

Bowman I. 1921: The new world: problems in political geography. - World Book Company, Yonkers-onHudson. 632 p.

CAPLES, M. 2005: Et in Hungaria ego: Trianon, revisionism and the journal Magyar Szemle (1927-1944). - Hungarian Studies 19. pp. 52-104.

Chisholm, G. G. 1919: Kéziratos jegyzetek. (Pontos dátum nélkül, valószínúleg 1919. december.) - University of Edinburgh, Centre for Research Collections, Chisholm Papers, Gen. 1060/79, f. 227.

Chisholm, G. G. 1924: George Goudie Chisholm levele Cholnoky Jenőnek, 1924. április 7. - Magyar Földrajzi Múzeum, Érd, Cholnoky Gyűjtemény.

Cholnoky J. 1942: Utazásom Amerikában Teleki Pál gróffal. - Vajda - Wichmann Kiadás, Budapest. 291 p.

Cholnoky J. 1998: Önéletrajz. - Vár ucca tizenhét 6. 2. pp. 185-339.

Clayton, D.-Barnes, T. 2015: Continental European geographers and World War II. - Journal of Historical Geography 47. pp. 11-15.

Clout, H. 2005: Lessons from experience: French geographers and the Transcontinental Excursion of 1912. - Progress in Human Geography 28. pp. 597-618.

DEÁK, F. 1942: Hungary at the Peace Conference: The diplomatic history of the Treaty of Trianon. - Columbia University Press, New York. 594 p. 
Demeter G.-Bottlik Zs.-Csaplár-Degovics K. 2015: Ethnic mapping on the Balkans (1840-1925): a brief comparative summary of concepts and methods of visualisation. - In: PEYKOVSKA, P.-DEMETER G. (szerk.): (Re)Discovering the sources of Hungarian and Bulgarian history. Institute of History, Bulgarian Academy of Sciences, Sofia-Budapest. pp. 65-100.

Dhand, O. 2018: The idea of Central Europe: Geopolitics, culture and regional identity. - I. B. Tauris, London. $288 \mathrm{p}$.

FILEP A. 2010: Kilencven éve jelent meg a történeti Magyarország részletes, 1:300.000 méretarányú nemzetiségi térképe I-II. - Geodézia és Kartográfia 62. 3. pp. 17-21., 62. 4. pp. 3-10.

FODOR F. 1920a: Economic-geographical map of Hungary: designed on the grounds of official data, in collaboration with Pal Teleki and Professor Eugene Cholnoky. - Hungarian Geographical Institute, Budapest.

FODOR F. 1920b: The geographical impossibility of the Czech state. - Low, Dawson \& Sons, London. $11 \mathrm{p}$.

FODOR F. 1928: The Treaty of Trianon in the light of geography. - In: APPONYI A. et. al. (szerk.): Justice for Hungary: Review and criticism of the effect of the Treaty of Trianon. Longmans, Green and Co., London. pp. 327-360.

FODOR F. 2006: A magyar földrajztudomány története. - MTA FKI, Budapest. 820 p.

FoDOR F. 2016: Élettörténet. - In: GYőRI R.- JoBBITT, S. (szerk.): Fodor Ferenc önéletírásai. ELTE Eötvös József Collegium, Budapest. pp. 235-350.

GELfAND, L. 1963: The inquiry: American preparations for peace. - Yale University Press, New Haven and London. 387 p.

GinsBuRger, N. 2016: Academic networks and scholarly circulation between wars and peace (1912-1919). The expertise of Jovan Cvijić and his colleague geographers through the cases of Trieste and Fiume. - Cybergeo, document 784. doi: 10.4000/cybergeo.27690.

GYURIS F. 2014: Human geography, cartography, and statistics: A toolkit for geopolitical goals in Hungary until World War II. - Hungarian Cultural Studies 7. pp. 214-241.

HAJDÚ Z. 1996: Az „államtáj” és a „tájállam” problematikája a magyar földrajztudományban 1948-ig. - Földrajzi Közlemények 120. 2-3. pp. 137-150.

HAJDÚ Z. 2000: A magyar földrajztudomány és a trianoni békeszerződés, 1918-1920. - Kisebbségkutatás 9. 2. pp. 224-233.

HefFERnAn, M. 1995: The spoils of war: the Société de Géographie de Paris and the French empire, 1914-1919. - In: Bell, M.-Butlin R. A.-HefFernan, M. (szerk.): Geography and Imperialism 1820-1940. Manchester University Press, Manchester. pp. 221-264.

HefFERnAN, M. 1996: Geography, cartography and military intelligence: The Royal Geographical Society and the First World War. - Transactions of the Institute of British Geographers 21. pp. 504-533.

Hinks, A. 1919: Arthur Hinks levele John Scott Keltie-nek, 1919. március 14. - RGS-IBG Archives, CB8.

Keltie J. S. 1919a: John Scott Keltie levele Arthur Hinks-nek, 1919. január 20. - RGS-IBG Archives, CB8.

Keltie, J. S. 1919b: John Scott Keltie levele Arthur Hinks-nek, 1919. március 13. - RGS-IBG Archives, CB8.

KEMÉNYFi R. 2006: Egységes magyar államtér alatt egységes kőzetalap: a Tisia-masszívum mítosza. - In: GYŐRI R.-HAJDÚ Z. (szerk.): Kárpát-medence: települések, tájak, régiók, térstruktúrák. Dialóg Campus Kiadó, Budapest-Pécs. pp. 418-438.

KEMÉNYFI R. 2010: Cartography as a tool of nation-building in Hungary and means of legitimizing Hungarian ethnic borders and spaces. - Hungarian Studies 24. 2. pp. 169-179.

KEMÉNYFi R. 2011: Nemzetiségi térképek mint a hatalmi beszédmód formái I-II. - Tér és Társadalom 25. 1. pp. 63-80. és 25. 2. pp. 69-87.

Kogutowicz K. 1927: Magyarország néprajzi térképe - Kókai, Budapest.

KonOPSKA, B. 2016: The cartographic materials auxiliary in the determination of the borders of Poland during the Paris Peace Conference 1919-1920. - Polish Cartographical Review 48. pp. 67-75.

KőSZEGI M.-BotTlik Zs. 2020: Maps in the service of science and politics in post-WWI Hungary. - In: JoBBITT, S.-GYŐRI R. (szerk.): Geography and the nation after Trianon. Routledge, London. (Megjelenés alatt.)

KRASZNAI Z. 2012: Földrajztudomány, oktatás és propaganda. (A nemzeti terület reprezentációja a két világháború közti Magyarországon.) - IDResearch Kft. - Publikon Kiadó, Pécs. 262 p.

LABBÉ, M. 2018: Eugene Romer's 1916 Atlas of Poland: creating a new nation state. - Imago Mundi 70. pp. 94-113.

LANSING, R. 1921: The peace negotiations: a personal narrative. - Houghton Mifflin, Boston and New York. 328 p.

LÉGRÁDY O. 1930: Justice for Hungary! The cruel errors of Trianon. - Nyomatott Légrády Testvérek Múintézetében, Budapest. 164 p.

MACARTNEY, C. 1937: Hungary and her successors: The Treaty of Trianon and its consequences 1919-1937.-Oxford University and the Royal Institute of International Affairs, London. 504 p.

Maclean, K. 2011: G. G. Chisholm, A. G. Ogilvie and the 1912 America transcontinental excursion. - Scottish Geographical Journal 127. pp. 231-248.

Macmillan, M. 2001: Peacemakers: the Paris Peace Conference of 1919 and its attempt to end war. - John Murray, London. 574 p. 
MADDRELL, A. 2008: 'Map girls': British women geographers' war work, shifting gender boundaries and reflection on the history of geography. - Transactions of the Institute of British Geographers 33. pp. 127-148.

MARTIN, G. 2015: American geography and geographers: Toward geographical science. - Oxford University Press, Oxford. 1240 p.

McFarlane, J. 1914: Economic geography. - Sir Isaac Pitman \& Sons Ltd., London. 560 p.

MFT 1918: A Magyar Földrajzi Társaság szózata a világ Földrajzi Társaságaihoz. - Földrajzi Közlemények 46. 7-9. pp. 289-320.

n.n. 1918: The geographical bearings of the armistice terms. - Scottish Geographical Magazine 34. pp. 441-448.

n.n. 1919: The American Geographical Society's contribution to the Peace Conference.-Geographical Review 7. pp. $1-10$.

n. n. 1920: Geography at the Congress of Paris, 1919. - The Geographical Journal 55. pp. 309-312.

n. n. 1920-1922: The Hungarian peace negotiations: An account of the work of the Hungarian Peace Delegation at Neuilly sur Seine, from January to March 1920. I-III. - Hornyánszky, Budapest.

Naval Intelligence Department 1919: The peoples of Austria-Hungary. I. Hungary. Atlas. - H. M. Government, London. $144 \mathrm{p}$

Newbigin, M. 1915a: Geographical aspects of Balkan problems. - John Constable, London. 243 p.

Newbigin, M. 1915b: The Balkan Peninsula: its peoples and its problems. - Scottish Geographical Magazine 31. pp. 281-303.

Newbigin, M. 1920: Aftermath: A geographical study of the peace terms.-W.\& A. K. Johnston. Edinburgh. 128 p.

Ogilvie, A. 1922: Some aspects of boundary settlement at the Peace Conference. - Society for Promoting Christian Knowledge, London. 34 p.

PALSKY, G. 2002: Emmanuel de Martonne and the ethnographical cartography of central Europe (1917-1920). - Imago Mundi 54. pp. 111-119.

Peterecz Z. 2017: Reflections of and about Hungary in the English-speaking world in the interwar years. - Hungarian Studies 31.2. pp. 237-250.

REISSER, W. 2012: The Black Book: Woodrow Wilson's secret plan for peace. - Lexington Books, Lanham MD. 214 p.

Romsics I. 2001: A trianoni békeszerződés. - Osiris Kiadó, Budapest. 246 p.

SEEGEL, S. 2018: Map men: Transnational lives and deaths of geographers in the making of East Central Europe. - University of Chicago Press, Chicago. 320 p.

SEGYEVy D. Z. 2016: Térképmúvek Trianon árnyékában. Magyarország néprajzi térképe (1918). - KSH Könyvtár, Budapest. 236 p.

Smith, N. 2003: American empire: Roosevelt's geographer and the prelude to globalization. - University of California Press, Berkeley. 592 p.

SzILÁGYI A. 2017: A tudományos nacionalizmus szolgálatában. A 19. századi földrajztudomány a nemzetépító diszciplínák között. - In: SzILÁGY A.-BollóK Á. (szerk.): Nemzet és tudomány Magyarországon a 19. században. MTA BTK Történettudományi Intézet, Budapest. pp. 58-75.

TeleKi P. 1918a: Teleki Pál levele Cholnoky Jenőnek, 1918. november 6. - Cholnoky Gyűjtemény, Magyar Földrajzi Múzeum, Érd.

TeleKi P. 1918b: Teleki Pál levele Isaiah Bowmannek, 1918. december 25. - American Geographical Society Library. University of Wisconsin-Milwaukee Libraries. American Geographical Society of New York Records, 1723-2010, bulk 1854-2000. AGSNY AC 1, Box 189, Folder 9. https://collections.lib.uwm.edu/digital/collection/agsny/id/45285T

TeleKi P. 1919a: Teleki Pál levele John Scott Keltie-nek, 1919. január 1. - RGS-IBG Archives, CB8.

TELEKI P. 1919b: Short notes on the economic and political geography of Hungary.-Hornyánszky, Budapest. 15 p. TELEKI P. 1919c: Magyarország néprajzi térképe a népsűrűség alapján. - Magyar Földrajzi Intézet, Budapest. TeleKi P. 1923: The evolution of Hungary and its place in European history. - Macmillan, New York. 312 p. Temperley, H. 1920: A history of the Peace Conference of Paris. I-VI. - Hodder and Stoughton, London. Zeidler M. 2009: A revíziós gondolat. - Kalligram Kiadó, Pozsony. 390 p.

ZEIDLER M. (szerk.) 2017a: A magyar békeküldöttség naplója, Neuilly-Versailles-Budapest (1920). - MTA BTK Történettudományi Intézet, Budapest. 312 p.

ZEIDLER M. 2017b: A magyar békedelegáció tevékenysége. - In: ZEIDLER M. (szerk.): A magyar békeküldöttség naplója, Neuilly-Versailles-Budapest (1920). MTA BTK Történettudományi Intézet, Budapest. pp. 13-44. 